\title{
PD-1, PD-L1 (B7-H1) and Tumor-Site Immune Modulation Therapy: The Historical Perspective
}

\author{
Jun Wang ${ }^{1}$, Ruirong Yuan ${ }^{2,3}$, Wenru Song ${ }^{3}$, Jingwei Sun ${ }^{1}$, Delong Liü ${ }^{3,4}$ and Zihai Li, ${ }^{3,5^{*}}$
}

\begin{abstract}
The current success of targeted inhibition against cytotoxic T-lymphocyte-associated protein 4 (CTLA-4) and Programmed Death 1/Programmed Death Ligand 1 (PD-1/PD-L1, herein collectively referred to as PD) pathways is hailed as a cancer immunotherapy breakthrough. PD-L1, known also as B7 homolog 1 (B7-H1), was initially discovered by Dr. Lieping Chen in 1999. To recognize the seminal contributions by Chen to the development of PD-directed therapy against cancer, the Chinese American Hematologist and Oncologist Network (CAHON) decided to honor him with its inaugural Lifetime Achievement Award in Hematology and Oncology at the CAHON's 2015 annual meeting. This essay chronicles the important discoveries made by Chen in the exciting field of immuno-oncology, which goes beyond his original fateful finding. It also argues that PD-directed therapy should be appropriately considered as Tumor-Site Immune Modulation Therapy to distinguish it from CTLA-4-based immune checkpoint blocking agents.
\end{abstract}

Keywords: B7-H1, PD-L1, PD-1, CTLA-4, CD28, immune checkpoint, immunotherapy, immuno-oncology, T cells, tumor-site immune modulation therapy

\section{Background}

Monoclonal antibodies targeting the PD pathway have become a critical breakthrough in our long fight against cancer [1, 2]. Distinct from any previous anti-cancer drugs, PD-based cancer therapy neither directly targets tumors, nor simply revamps the immune system nonspecifically. It depends on the strategic modulation of a key tumor immune evasive mechanism featured by the PD-L1 (B7-H1) molecule, and controls tumor growth by resetting immune responses in the tumor microenvironment to the homeostatic and beneficial level [3, 4]. Currently, several anti-PD therapeutic agents have been approved for the treatment of multiple cancer types including lung cancer, head and neck cancer, melanoma and others in the United States, Europe, as well as in Japan and other parts of the world. Numerous clinical trials are ongoing worldwide in order to broaden and increase the utility of anti-PD therapeutics to most if not all human

\footnotetext{
* Correspondence: zihai@musc.edu

${ }^{3}$ The Chinese American Hematologist and Oncologist Network (CAHON), Scarsdale, NY 11577, USA

${ }^{5}$ Medical University of South Carolina, Charleston, SC 29425, USA

Full list of author information is available at the end of the article
}

cancers, thanks to the impressive clinical efficacy with favorable toxicities of these novel agents. The successful development of PD-modulating medicines has revolutionized the field of immuno-oncology in an unprecedented way, and opens the door for Tumor-Site Immune Modulation Therapy [5] that will profoundly impact basic and clinical immune-oncology research. Indeed, many outstanding reviews have been written on this topic [3-12]. Nevertheless, in this essay, we review the key milestones in the history of anti-PD drug development, and specifically highlight some of Lieping Chen's contributions to this revolutionary cancer treatment modality.

\section{History of anti-PD drug development and the roles of Lieping Chen}

The success of anti-PD drug development benefited from the advancement of our fundamental understanding of both cancer biology and the immune system. Cancer originates from the mutated self of the host in the setting of genotoxic insults with molecular hallmarks of genetic instability and heterogeneity $[13,14]$. Most conventional therapies, including radiation, chemotherapy 
and even molecular-targeted therapies, directly target cancers themselves with improving, but still less desirable efficacy due to significant side-effects, drug resistance and recurrence of more aggressive malignant clones $[8,13,15]$. The limitations of conventional therapies are especially evident for late stage and advanced cancers. In contrast, the immune system, especially the adaptive arm of immunity such as T cells, is capable of surveilling against mutated antigens in tumor cells and controlling tumor growth through specific immune effector mechanisms. Importantly, these immune cells evolve in parallel with tumors, and are capable of sustainable tumor recognition and killing $[16,17]$. However, surveillance efficacy often fails due to multiple tumor immune evasive mechanisms, resulting in the outgrowth and metastasis of cancer cells $[18,19]$. Efforts in understanding the basic mechanisms of immune tolerance in general and the primary immune evasive mechanisms by cancer cells in particular have been the key to the successful development of drugs targeting the PD-1/PD-L1 pathway.

Many individuals contributed to the success of PDdirected cancer therapy (Table 1 and Fig. 1) [2]. Among them, Lieping Chen's work is the focus of this review. In the early span of the 1990s, Chen was convinced that in the tumor microenvironment, there exist specific molecular pathways that are primarily responsible for immune evasion, and that this concept could be harnessed for more effective cancer therapy. His passion has been devoted towards the search for these elusive molecules ever since. Trained as a physician-scientist in China, Chen quickly became convinced that basic medical research holds the key to cancer cure. He earned his M.S. degree at the Cancer Institute of Peking Union Medical College in 1986 before obtaining his Ph.D. from Drexel University in 1989. He then undertook his postdoctoral training at the University of Washington, Seattle in 1990, all along focusing on immunology. During that period, important discoveries were made regarding the major immune cell populations with different immune functions, distinguished by cell surface molecules,

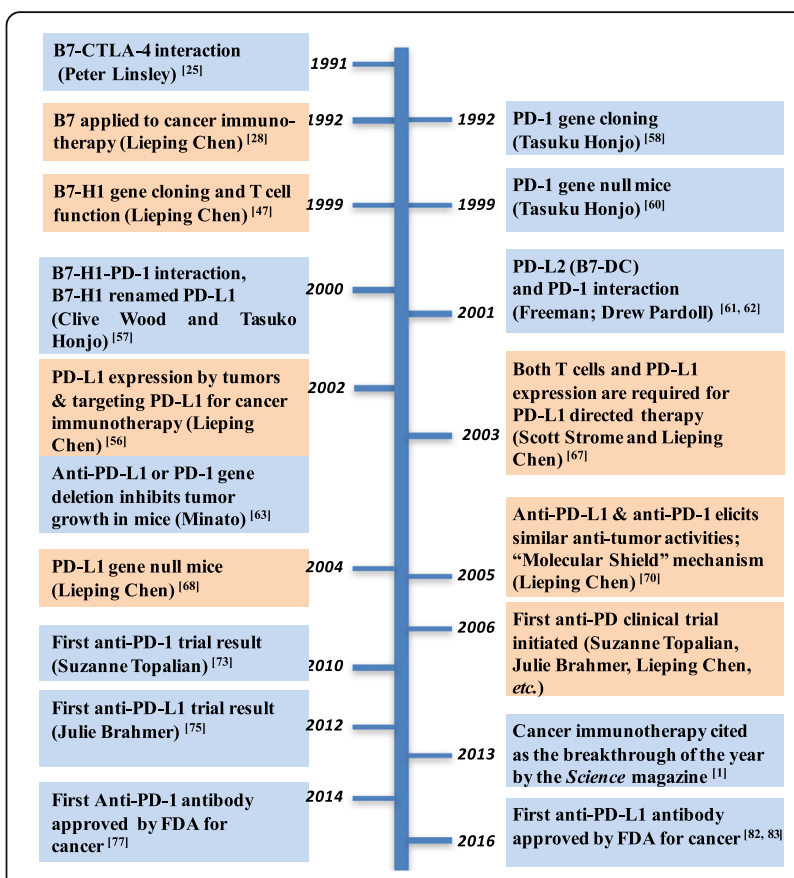

Fig. 1 Timeline for major events leading to the development of anti-PD drugs. The contributions by Lieping Chen are highlighted in light orange. The contributions by Lieping Chen are highlighted in light orange

including CD3, CD4, CD8, T cell receptor (TCR) and others [20-23]. More importantly, the guiding principle of $\mathrm{T}$ cell activation and tolerance began to emerge [21]. Among those important events, the discovery of CD28, CTLA-4 and their ligands B7 (B7.1 and B7.2) was the key development in the field $[24,25]$ which vindicated the two-signal hypothesis for lymphocyte activation proposed by Bretscher and Cohn [26], and extended by Lafferty and his colleagues [27]. The first signal is via TCR triggered by an $\mathrm{MHC}$-antigenic peptide complex, whereas the second signal, also known as a co-stimulation signal, is provided by co-stimulatory molecules expressed on the surface of antigen presenting cells (APC) and T cells (like B7-CD28 pathway). Based on this principle, Chen and his

Table 1 Major contributions to the development of targeted cancer immunotherapeutics against CTLA-4 and PD-1/PD-L1 Pathways ${ }^{\text {a }}$

\begin{tabular}{|c|c|c|c|}
\hline Contributions & CTLA-4 & PD-1 & PD-L1 (B7-H1) \\
\hline Gene Cloning & Pierre Goldstein (1987) [59] & Tasuku Honjo (1992) [57] & Lieping Chen (1999) [47] \\
\hline Inhibitory Function & $\begin{array}{l}\text { Jeffery Bluestone (1994) [30] } \\
\text { Arlene Sharpe (1995) [32] } \\
\text { Tak Mak (1995) [33] }\end{array}$ & Tasuku Honjo (1999) [60] & $\begin{array}{l}\text { Lieping Chen (1999) [47] } \\
\text { Tasuku Honjo, Clive Wood (2000) [57] b } \\
\text { Lieping Chen (2004) [68] }\end{array}$ \\
\hline Ligand-receptor Interaction & Peter Linsley (1991) [25] & Tasuku Honjo, Clive Wood (2000) [57] b & Tasuku Honjo, Clive Wood (2000) [57] ${ }^{\text {b }}$ \\
\hline Function in cancer immunity & James Allison (1996) [34] & $\begin{array}{l}\text { NagahiroMinato (2002) [63] } \\
\text { Lieping Chen (2005) [70] } \\
\text { Tasuku Honjo (2005) [71] }\end{array}$ & $\begin{array}{l}\text { Lieping Chen (2002) [56] } \\
\text { Nagahiro Minato (2002) [63] }\end{array}$ \\
\hline
\end{tabular}

a The discovery of PD-L2 was made by Gordon Freeman and Arlene Sharpe (2001)[61], and Drew Pardoll (2001)[62]. Subsequent work on PD-L2 is not highlighted here

${ }^{\mathrm{b}}$ Gordon Freeman, Andrew Long and Yoshiko Iwai are the three co-first authors of this work, which renamed B7-H1 (its gene cloned one year earlier) to PD-L1 
colleagues, for the first time, demonstrated that stablyenforced expression of B7 molecules in cancer cells elicited strong anti-tumor immune responses, leading to eradication of distal tumors [28]. This effect is mainly CD28 dependent: upon ligation of the same B7 ligand, CD28 delivers an essential signal for naïve $\mathrm{T}$ cell activation [29], which is in contrast to the CTLA-4 molecule behaving as a $\mathrm{T}$ cell "checkpoint" receptor with inhibitory activities [30-33]. Blocking CTLA-4 for immunotherapy of cancer was later steered by James Allison who has played crucial roles in the renaissance of cancer immunology [34-37], whereas Chen's earlier work laid the groundwork for the therapeutic potential of manipulating co-stimulatory molecules against cancer. However, the ectopic expression of costimulatory molecules like B7 on tumor cells worked effectively against multiple murine tumor models, its application is currently limited in cancer patients [38]. Additionally, since both B7 ligands and CD28/CTLA-4 receptors are expressed broadly without tumor specificity and that they play essential roles in the control of general immune homeostasis, targeting this pathway could be met with severe autoimmune toxicities, which was shown to be the case in the clinical trials of TGN1412, an antiCD28 super agonist antibody [39], and the anti-CTLA-4 antibodies, ipilimumab and tremelimumab [40-42]. Chen was determined to uncover tumor-specific immune evasion mechanisms and find ways to block them.

During his seven-year tenure at Bristol-Myers Squibb (1990-1997), Lieping Chen evaluated the immune functions and potential anti-tumor effects of many cell surface molecules on $\mathrm{T}$ cells, especially 4-1BB (CD137), a molecule specifically expressed by activated $\mathrm{T}$ cells and serving as another co-stimulatory receptor. The Chen group were the first to reveal the potent anti-tumor effect of the anti-4-1BB agonistic antibody in both immunogenic and non-immunogenic tumor models [43], making 4-1BB an attractive target for immuno-oncology [44]. Some promising results from the anti-4-1BB clinical trials were recently reported [45]. Although the expression of 4-1BB ligand is relatively broad, 4-1BB expression could accurately identify tumor-reactive $\mathrm{T}$ cells [46]. Even so, Chen believed that immune-regulatory molecules with higher tumor specificity remained to be identified. He returned to academia and joined the Mayo Clinic to continue searching for these pathways. Inspired by the progress of the Human Genome Project, Chen turned to informatics to discover candidate molecules from the human expressed sequence tag (EST) libraries based on their predicted homology to B7 family molecules. This effort was incredibly successful; he made several seminal discoveries of a series of novel B7 family members, including B7-H1 (PD-L1) [47], B7-H2 [48], B7-H3 [49], B7-H4 [50], B7-H5 [51], PD-1H (VISTA) [52] and so on [53-55]. In a series of papers, Chen and his colleagues completed the fundamental characterization of the B7-H1's biological function and provided the very first proof of anti-tumor effects via blockade of B7-H1 $[47,56]$, which mainly serve as a ligand to PD-1 receptor on T cells [57], a molecule discovered earlier by Tasuku Honjo in Japan [58]. In 2004, Chen joined the Johns Hopkins University School of Medicine and collaborated with Suzanne Topalian, Julie Brahmer and other clinical investigators to initiate the first clinical trial of anti-PD-1/PD-L1 pathway therapies in patients with cancer. It was this clinical study that opened the floodgate of PD-1/PD-L1 pathway-directed cancer immunotherapy.

The key events that led to the successful development of anti-CTLA-4 and anti-PD-1/PD-L1 drugs are chronicled below (Fig. 1 and Table 1):

- From 1990 to 1991, Peter Linsley from the BristolMyers Squibb discovered the interaction between CD28, CTLA-4, and B7 [24, 25]. The B7 pathway was later generally considered as an essential co-stimulatory molecule for naïve $\mathrm{T}$ cell activation $[21,54]$.

- In 1992, by stably expressing B7 molecule in the tumor cells, Lieping Chen provided the theoretical basis for the therapeutic potential of manipulating the expression of co-stimulatory molecules in the tumor microenvironment for cancer immunotherapy $[28,29]$.

- In 1992, Tasuku Honjo cloned the PD-1 gene (Pdcd1) from immune cell lines undergoing apoptosis [58].

- In 1994, Jeffery Bluestone first identified the inhibitory function of CTLA-4, and also categorized CTLA-4 as the first cell surface $\mathrm{T}$ cell inhibitory receptor [30]*"

"Note: During the process of drug development targeting this molecule, Pierre Goldstein cloned CTLA-4 gene (Ctla4) [59] and Peter Linsley discovered the receptor-ligand interaction between $\mathrm{B} 7$ and CTLA-4 [25] (Table 1). Arlene Sharpe and Tak Mak subsequently reported the fatal autoimmune diseases of Ctla4-deficient mice [32, 33]. James Allison characterized the anti-tumor effect of antibody targeting CTLA-4 [34]. The anti-CTLA-4 antibody, ipilimumab, was later approved by the U.S. Food and Drug Administration (FDA) for treatment of melanoma in 2011 [37].

- In 1997, Lieping Chen identified the potent antitumor effect of agonistic antibody targeting 4-1BB, another co-stimulatory receptor on $\mathrm{T}$ cells, which further inspired the field of cancer immunotherapy [43].

- Around 1997, given the progress of the Human Genome Project, Lieping Chen's group started to search for B7-like molecules from the human EST 
libraries, thus began his seminal works on expanding the members of the B7 family.

- In 1999, Chen cloned the first B7 homolog, the human B7-H1 gene, and identified its inhibitory activity on T cells by inducing IL-10 [47]. During the following years, Chen's group also cloned B7-H2 [48], B7-H3 [49], B7-H4 [50], B7-H5 [51] and PD-1H [52].

- In 1999, Tasuku Honjo discovered that the PD-1 gene (Pdcd1) knockout mice have mild autoimmune symptoms, which revealed the inhibitory function of PD-1 in preventing autoimmunity [60].

- In 2000, Tasuku Honjo and Clive Wood discovered the interaction between B7-H1 and PD-1, and changed the name of B7-H1 to PD-L1 [57].

- In 2001, Arlene Sharpe and Gordon Freeman discovered another PD-1 ligand, PD-L2 (Programmed Death Ligand 2), which also shows inhibitory activity to T cells [61]. Drew Pardoll's group identified PD-L2 around the same time, and named this molecule B7-DC for its specific expression on dendritic cells [62].

- In 2002, Lieping Chen discovered the critical role of B7-H1 (PD-L1) as a potential immune evasion mechanism in the tumor microenvironment. B7-H1 is found to be overexpressed in many human tumor tissues, but minimally detected in the normal tissues, which was mainly regulated by IFN- $\gamma$ [56]. Most importantly, antibody-targeting B7-H1 could restore T cell function and control tumor growth both in vitro and in vivo [56]. Subsequent works by Nagahiro Minato [63] and Weiping Zou [64] further supported this finding. Moreover, Chen's study suggested the existence of other receptor(s) for B7-H1, which was later validated by a follow-up mutation study made by Chen [65], and finally led to the discovery of B7-1 as another B7-H1 inhibitory receptor by Arlene Sharpe and Gordon Freeman [66].

- In 2003, Scott Strome and Lieping Chen showed that B7-H1 overexpression in tumor cells and $\mathrm{T}$ cell activation are two indispensable pre-conditions for the potent anti-cancer effect of antibodies blocking this pathway [67].

- In 2004, Lieping Chen discovered that the B7-H1 gene $(C d 274)$ null mice have some spontaneous accumulation of activated $\mathrm{CD} 8^{+} \mathrm{T}$ cells in the liver, but do not have overt autoimmune manifestations. This work further proved the inhibitory function of B7-H1 and predicted the acceptable safety profile of B7-H1-targeted therapy [68]. An independent study by Arlene Sharpe and Gordon Freeman using Cd274deficient mice also proved that PD-L1 negatively regulates $\mathrm{T}$ cells [69].

- In 2004, Lieping Chen joined the Johns Hopkins University School of Medicine, and contributed to the development of the first-in-human trial concept on antibodies targeting the PD-1/PD-L1 pathway for the treatment of advanced cancers.

- In 2005, Lieping Chen demonstrated that antibodies blocking either B7-H1 or PD-1 could promote antitumor immune responses, and proposed the "Molecular Shield" mechanism of PD-L1 on tumors that offers resistance to cytotoxic T lymphocytes (CTL) [70]. Tasuku Honjo also demonstrated that PD-1 blockade by genetic manipulation or antibody treatment inhibited hematogenous spreading of tumor cells [71].

- In 2006, Rafi Ahmed characterized a role of the PD1/PD-L1 pathway in T cell exhaustion with the lymphocytic choriomeningitis virus (LCMV) chronic infection model [72].

- In 2006, the first human cancer clinical trial targeting the PD-1/PD-L1 pathway was launched in the Johns Hopkins Hospital.

- In 2010, the first clinical observation on anti-PD-1 treatment was reported by Suzanne Topalian [73].

- In 2012, the results of the first two large anti-PD-1 and anti-PD-L1 clinical trials in the Johns Hopkins Hospital, the Yale-New Haven Hospital and others were reported [74, 75].

- In 2006, Lieping Chen's group developed a sensitive and effective immunohistochemistry staining protocol for detecting PD-L1 expression in cancer cells, and pointed out the value of PD-L1 staining in tumor sections on the prediction of anti-PD-1/PDL1 clinical efficacy in 2012. Chen also refined his theory on anti-PD-1/PD-L1 therapy by proposing the adaptive resistance concept [76].

- In 2013, cancer immunotherapy was selected as the breakthrough of the year by the Science magazine [1, 2].

- In 2014, anti-PD-1 antibodies (nivolumab and pembrolizumab) were approved in the United States and Japan for treatment of advanced metastatic melanoma [77], and subsequently for treatment of many other cancer types in 2015-2016 [78-82].

- In 2016, the anti-PD-L1 antibody, atezolizumab, was approved by the FDA for the treatment of advanced urothelial carcinoma and non-small cell lung cancer $[82,83]$.

\section{Anti-PD modality and tumor-site immune modulation therapy}

The timeline in the history of anti-PD drug development (Fig. 1) spans from the understanding of the B7 pathway in regulating $\mathrm{T}$ cell responses to the discovery of the $\mathrm{PD}$ pathway with tumor-site immune modulation properties, reflecting our increased understanding of both $\mathrm{T}$ cell biology and tumor immunity. This advancement resulted from the progress of research in the field of both 
immunology and oncology, eventually leading to the birth of immuno-oncology. Ironically, anti-PD antibodies did not show clear anti-tumor effects in many animal models in the early days of research, raising skepticism among many over their therapeutic application. However, Lieping Chen and his colleagues proposed that the potency of anti-PD therapy depends on both the existence of immune cells especially $\mathrm{T}$ cells in the tumor site, as well as PD-L1 expression by the tumor cells [67, 70, 84]. He steadfastly and passionately championed the clinical development of agents targeting this pathway. Thus, Chen played key roles in advancing the anti-PD drug program in the areas of basic research as well as in clinical translation (Table 1), for which he was recognized with the 2014 William Coley Award in Basic and Tumor Immunology [85] (shared with Tasuku Honjo, Arlene Sharpe and Gordon Freeman), the 2015 Lifetime Achievement Award in Hematology and Oncology by CAHON (www.cahon.org, and this paper), and the 2016 American Association of Immunologists (AAI)Steinman Award for Human Immunology Research (http://www.aai.org/Awards/Archive/index.html).

Targeting the PD pathway for treatment of cancer is unique in several aspects, including the following (Figs. 2 and 3):

First, the action of anti-PD therapy is primarily localized to the tumor site. The ligand for PD-1, PD-L1 (B7$\mathrm{H} 1$ ), has high expression on tumor cells. It is absent in the majority of normal tissues, but could be induced in the tumor microenvironment by ongoing immune responses, mostly by the cytokine IFN- $\gamma[3,56]$. This tumor-localized effect of PD-L1 dictates that the antibodies targeting either ligand or receptor will work in the tumor microenvironment with ongoing immune responses. In contrast, PD-L2, another ligand of PD-1, has weak expression in tumors and is constitutively expressed by dendritic cells $[53,54]$. The expression pattern of PD-L2 likely explains why targeting PD-L2 has only minor anti-tumor effects, although PD-L2 and PDL1 have similar binding affinity to PD-1, and their inhibitory effects on T cells in vitro are comparable.

Second, targeting the PD pathway repairs or resets tumor-associated immune defects. The PD-L1 molecule is a key mechanism for tumor-mediated immune evasion [3]. The ligation of PD-L1 to PD-1 causes functional defects in $\mathrm{T}$ cells through several different mechanisms (Fig. 2), including anergy to antigen stimulation [86-88], functional exhaustion [72], apoptosis [56], induction of immune suppressor cells $[89,90]$, and secretion of inhibitory cytokines, such as IL-10 [47]. PD-1 on myeloid cells also impairs dendritic cell functions [91]. In addition, PD-L1 reverse-signaling on tumor cells was found to serve as a "Molecular Shield," protecting the tumor from killing by CTLs [70, 92]. Importantly, this

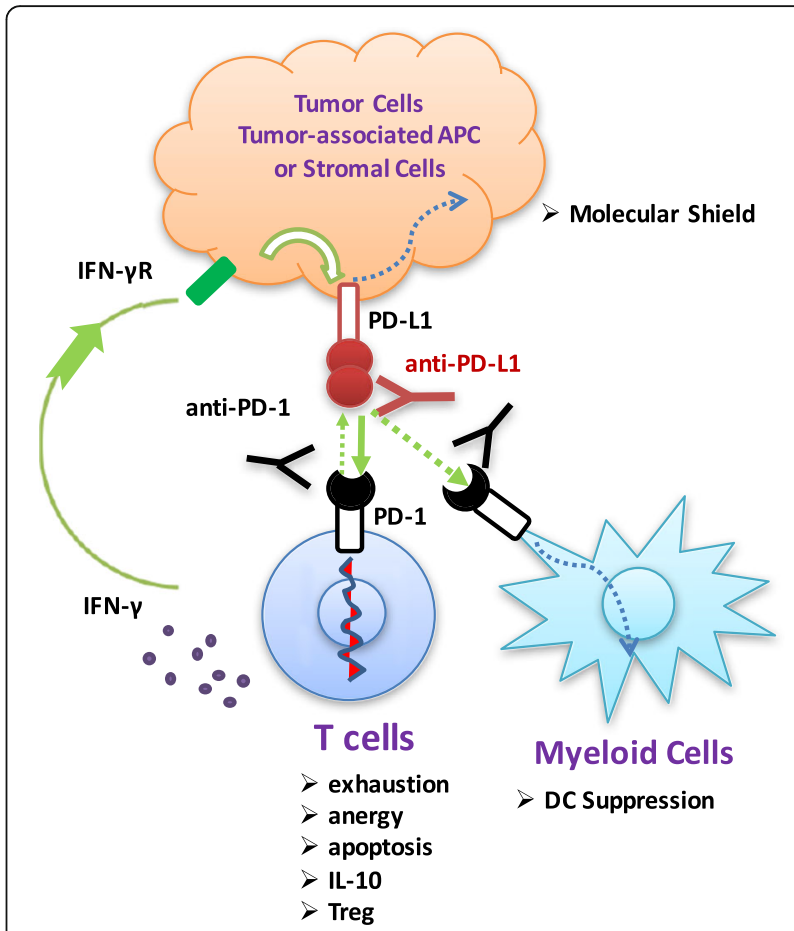

Fig. 2 Mechanism of the PD pathway in driving tumor-associated immune evasion. Tumor cells, tumor-associated antigen-presenting cells (APCs), and stromal cells upregulate PD-L1 in response to ongoing immune responses, mainly through the action of IFN- $\gamma$. The ligation of PD-1 by PD-L1 delivers inhibitory signals to T cells, leading to $T$ cell anergy, functional exhaustion, and apoptosis. PD-1PD-L1 interaction also favors conversion of T cells to the regulatory $T$ cell (Treg) phenotype with secretion of inhibitory cytokines, such as IL10. PD-1 on myeloid cells also impairs dendritic cell functions. In addition, PD-L1 reversed signaling on tumor cells can serve as a "Molecular Shield" protecting tumor cells from CTL-mediated killing. IFN- $\mathrm{R}$ : IFN- $\gamma$ receptor

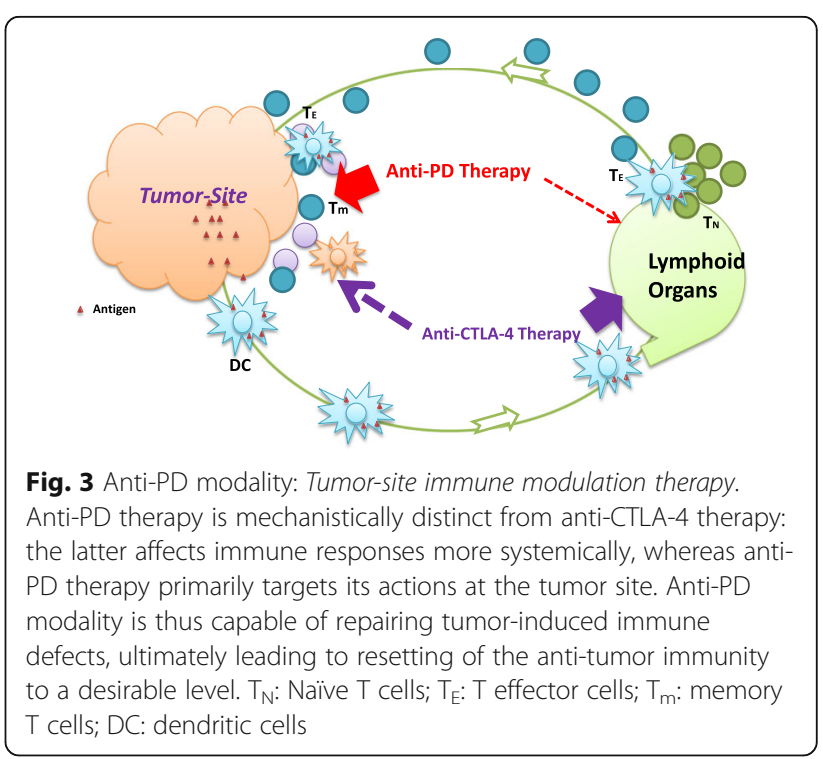


type of immune defect is not permanent, and can be restored by termination of this pathway, especially by the antibody blockade of either PD-L1 or PD-1 [70]. Moreover, anti-PD therapy may reset the global anti-tumor immune defects possibly by yet unknown "cascade reaction" mechanisms, as profound and sustainable therapeutic effects have been observed in many patients receiving this therapy [3].

Third, the PD blockade aims to normalize the antitumor immune response but not over-exuberate immune responses in general. Blockade of either PD-L1 or PD-1 is not to simply amplify immunity, but to re-adjust the anti-tumor immune responses to a desirable level (Fig. 3). Given the mild and rare autoimmune symptoms observed in PD-L1 and PD-1 gene-deficient mice [60, 68] and weak expression of these molecules by normal tissues [56, 93], targeting the PD pathway in the tumor settings will normalize anti-tumor immunity but spare the normal peripheral tolerance mechanism against self-antigens [3]. Thus, anti-PD treatment has an understandably great safety window [94].

These abovementioned features of the PD pathway are very unique among the many pathways currently tested for cancer immunotherapy. Strictly speaking, PD-1/PDL1 is the only known pathway responsible for key tumor-specific immune evasion mechanisms so far. Yet, both PD-1/PD-L1 and CTLA-4 are often lumped together as "immune checkpoints" [6, 8, 31, 95], which is an immunological term defining a plethora of inhibitory pathways in the control of physiological immune responses [6]. This concept does not distinguish the immune modulating role of anti-PD therapy from the actions of anti-CTLA-4 therapy [3, 7] (Fig. 3). An alternative term of "Tumor-Site Immune Modulation Therapy" might better describe the attributes of anti-PD therapy [5], which is characterized by targeting molecules responsible for tumor-site specific immune evasion mechanisms, resetting and restoring the anti-tumor immunity back to a desirable level. Such action is clearly different from CTLA-4 blockade, which overdrives systemic T cell immunity including self-reactive $\mathrm{T}$ cell responses.

Lieping Chen continues his journey to discover more PD-like molecules, aiming to convert human cancers to chronic and manageable diseases via exploiting the power of the hardwired immune system. His contributions to this field have cemented his place in immunooncology.

\section{Acknowledgements}

We thank many members of CAHON for stimulating discussions on the topic.

\section{Funding}

Z.L. is supported by the U.S. National Institutes of Health grants DK105033, CA186866, CA188419 and Al070603.
Availability of data and materials

The material supporting the conclusion of this review has been included within the article.

\section{Authors' contributions}

All authors discussed the topic, contributed to the drafting of the manuscript and approved the final manuscript.

\section{Competing interests}

The authors declare that they have no competing interests.

\section{Consent for publication}

This is not applicable to this review.

Ethics approval and consent to participate

This is not applicable to this review.

\section{Author details}

${ }^{1}$ Yale University School of Medicine, New Haven, CT 06510, USA. ${ }^{2}$ Veterans Health Administration Medical Center, East Orange, NJ 07018, USA. ${ }^{3}$ The Chinese American Hematologist and Oncologist Network (CAHON), Scarsdale, NY 11577, USA. ${ }^{4}$ New York Medical College, Valhalla, NY 10595, USA. ${ }^{5}$ Medical University of South Carolina, Charleston, SC 29425, USA.

Received: 7 January 2017 Accepted: 13 January 2017

Published online: 25 January 2017

\section{References}

1. Couzin-Frankel J. Breakthrough of the year 2013. Cancer Immunother Sci. 2013;342(6165):1432-3.

2. $\quad$ Pardoll D. Immunotherapy: it takes a village. Science. 2014;344(6180):149.

3. Chen L, Han X. Anti-PD-1/PD-L1 therapy of human cancer: past, present, and future. J Clin Invest. 2015;125(9):3384-91.

4. Zou W, Wolchok JD, Chen L. PD-L1 (B7-H1) and PD-1 pathway blockade for cancer therapy: Mechanisms, response biomarkers, and combinations. Sci Transl Med. 2016;8(328):328rv324.

5. Chen L. From the guest editor: Tumor site immune modulation therapy. Cancer J. 2014;20(4):254-5.

6. Pardoll DM. The blockade of immune checkpoints in cancer immunotherapy. Nat Rev Cancer. 2012;12(4):252-64.

7. Okazaki T, Chikuma S, Iwai Y, Fagarasan S, Honjo T. A rheostat for immune responses: the unique properties of PD-1 and their advantages for clinical application. Nat Immunol. 2013;14(12):1212-8.

8. Sharma P, Allison JP. Immune checkpoint targeting in cancer therapy: toward combination strategies with curative potential. Cell. 2015;161(2): 205-14.

9. Chen DS, Mellman I. Oncology meets immunology: the cancer-immunity cycle. Immunity. 2013:39(1):1-10.

10. Lesokhin AM, Callahan MK, Postow MA, Wolchok JD. On being less tolerant: enhanced cancer immunosurveillance enabled by targeting checkpoints and agonists of T cell activation. Sci Transl Med. 2015;7(280):280sr281.

11. Boussiotis VA. Molecular and Biochemical Aspects of the PD-1 Checkpoint Pathway. N Engl J Med. 2016;375(18):1767-78.

12. Topalian SL, Drake CG, Pardoll DM. Immune checkpoint blockade: a common denominator approach to cancer therapy. Cancer Cell. 2015;27(4): 450-61.

13. Hanahan D, Weinberg RA. Hallmarks of cancer: the next generation. Cell. 2011;144(5):646-74.

14. Vogelstein B, Papadopoulos N, Velculescu VE, Zhou S, Diaz Jr LA, Kinzler KW. Cancer genome landscapes. Science. 2013;339(6127):1546-58.

15. Qiao J, Liu Z, Fu YX. Adapting conventional cancer treatment for immunotherapy. J Mol Med (Berl). 2016:94(5):489-95.

16. Gajewski TF, Schreiber H, Fu YX. Innate and adaptive immune cells in the tumor microenvironment. Nat Immunol. 2013;14(10):1014-22.

17. Schreiber RD, Old LJ, Smyth MJ. Cancer immunoediting: integrating immunity's roles in cancer suppression and promotion. Science. 2011; 331(6024):1565-70.

18. Swann JB, Smyth MJ. Immune surveillance of tumors. J Clin Invest. 2007; 117(5):1137-46. 
19. Mittal D, Gubin MM, Schreiber RD, Smyth MJ. New insights into cancer immunoediting and its three component phases-elimination, equilibrium and escape. Curr Opin Immunol. 2014;27:16-25.

20. Reinherz EL. Revisiting the Discovery of the alphabeta TCR Complex and Its Co-Receptors. Front Immunol. 2014;5:583.

21. Schwartz RH. Historical overview of immunological tolerance. Cold Spring Harb Perspect Biol. 2012;4(4):a006908.

22. Eisen HN, Schlesinger S. Remembrance of immunology past: conversations with Herman Eisen. Annu Rev Immunol. 2015;33:1-28.

23. Mak TW. The T cell antigen receptor: "The Hunting of the Snark". Eur J Immunol. 2007;37 (Suppl 1):S83-93.

24. Linsley PS, Clark EA, Ledbetter JA. T-cell antigen CD28 mediates adhesion with $B$ cells by interacting with activation antigen B7/BB-1. Proc Natl Acad Sci U S A. 1990;87(13):5031-5.

25. Linsley PS, Brady W, Urnes M, Grosmaire LS, Damle NK, Ledbetter JA. CTLA-4 is a second receptor for the B cell activation antigen B7. J Exp Med. 1991; 174(3):561-9.

26. Bretscher P, Cohn M. A theory of self-nonself discrimination. Science. 1970; 169(950):1042-9.

27. Lafferty KJ, Prowse SJ, Simeonovic CJ, Warren HS. Immunobiology of tissue transplantation: a return to the passenger leukocyte concept. Annu Rev Immunol. 1983;1:143-73.

28. Chen L, Ashe S, Brady WA, Hellstrom I, Hellstrom KE, Ledbetter JA, McGowan P, Linsley PS. Costimulation of antitumor immunity by the B7 counterreceptor for the T lymphocyte molecules CD28 and CTLA-4. Cell. 1992;71(7):1093-102.

29. Chen L, Linsley PS, Hellstrom KE. Costimulation of T cells for tumor immunity. Immunol Today. 1993;14(10):483-6.

30. Walunas TL, Lenschow DJ, Bakker CY, Linsley PS, Freeman GJ, Green JM, Thompson CB, Bluestone JA. CTLA-4 can function as a negative regulator of T cell activation. Immunity. 1994;1(5):405-13.

31. Korman AJ, Peggs KS, Allison JP. Checkpoint blockade in cancer immunotherapy. Adv Immunol. 2006;90:297-339.

32. Tivol EA, Borriello F, Schweitzer AN, Lynch WP, Bluestone JA, Sharpe AH. Loss of CTLA-4 leads to massive lymphoproliferation and fatal multiorgan tissue destruction, revealing a critical negative regulatory role of CTLA-4. Immunity. 1995;3(5):541-7.

33. Waterhouse $P$, Penninger JM, Timms E, Wakeham A, Shahinian A, Lee KP, Thompson CB, Griesser H, Mak TW. Lymphoproliferative disorders with early lethality in mice deficient in Ctla-4. Science. 1995;270(5238):985-8.

34. Leach DR, Krummel MF, Allison JP. Enhancement of antitumor immunity by CTLA-4 blockade. Science. 1996;271(5256):1734-6.

35. Hodi FS, O'Day SJ, McDermott DF, Weber RW, Sosman JA, Haanen JB, Gonzalez R, Robert C, Schadendorf D, Hassel JC, et al. Improved survival with ipilimumab in patients with metastatic melanoma. N Engl J Med. 2010;363(8):711-23.

36. Robert C, Thomas L, Bondarenko I, O'Day S, Weber J, Garbe C, Lebbe C, Baurain JF, Testori A, Grob JJ, et al. Ipilimumab plus dacarbazine for previously untreated metastatic melanoma. N England J Med. 2011;364(26):2517-26.

37. Cameron F, Whiteside G, Perry C. Ipilimumab: first global approval. Drugs. 2011:71(8):1093-104

38. Singh P, Pal SK, Alex A, Agarwal N. Development of PROSTVAC immunotherapy in prostate cancer. Future Oncol. 2015;11(15):2137-48.

39. Suntharalingam G, Perry MR, Ward S, Brett SJ, Castello-Cortes A, Brunner $\mathrm{MD}$, Panoskaltsis N. Cytokine storm in a phase 1 trial of the anti-CD28 monoclonal antibody TGN1412. N Engl J Med. 2006;355(10):1018-28.

40. Fecher LA, Agarwala SS, Hodi FS, Weber JS. Ipilimumab and its toxicities: a multidisciplinary approach. Oncologist. 2013;18(6):733-43.

41. Ribas A, Kefford R, Marshall MA, Punt CJ, Haanen JB, Marmol M, Garbe C, Gogas H, Schachter J, Linette $\mathrm{G}$, et al. Phase III randomized clinical trial comparing tremelimumab with standard-of-care chemotherapy in patients with advanced melanoma. J Clin Oncol. 2013;31(5):616-22.

42. Ibrahim RA, Berman DM, DePril V, Humphrey RW, Chen T, Messina M, Chin KM, Liu HY, Bielefield M, Hoos A. Ipilimumab safety profile: Summary of findings from completed trials in advanced melanoma. J Clin Oncol. 2011; 29(15_suppl):8583

43. Melero I, Shuford WW, Newby SA, Aruffo A, Ledbetter JA, Hellstrom KE, Mittler RS, Chen L. Monoclonal antibodies against the 4-1BB T-cell activation molecule eradicate established tumors. Nat Med. 1997;3(6):682-5.

44. Sanmamed MF, Pastor F, Rodriguez A, Perez-Gracia JL, Rodriguez-Ruiz ME, Jure-Kunkel M, Melero I. Agonists of Co-stimulation in Cancer Immunotherapy Directed Against CD137, OX40, GITR, CD27, CD28, and ICOS. Semin Oncol. 2015;42(4):640-55.
45. Chester C, Ambulkar S, Kohrt HE. 4-1BB agonism: adding the accelerator to cancer immunotherapy. Cancer Immunol Immunother. 2016;65(10):1243-8.

46. Ye Q, Song DG, Poussin M, Yamamoto T, Best A, Li C, Coukos G, Powell Jr DJ. CD137 accurately identifies and enriches for naturally occurring tumorreactive T cells in tumor. Clin Cancer Res. 2014;20(1):44-55.

47. Dong H, Zhu G, Tamada K, Chen L. B7-H1, a third member of the B7 family, co-stimulates T-cell proliferation and interleukin-10 secretion. Nat Med. 1999;5(12):1365-9.

48. Wang S, Zhu G, Chapoval Al, Dong H, Tamada K, Ni J, Chen L. Costimulation of T cells by B7-H2, a B7-like molecule that binds ICOS. Blood. 2000;96(8): 2808-13.

49. Chapoval Al, Ni J, Lau JS, Wilcox RA, Flies DB, Liu D, Dong H, Sica GL, Zhu G, Tamada K, et al. B7-H3: a costimulatory molecule for T cell activation and IFN-gamma production. Nat Immunol. 2001;2(3):269-74.

50. Sica GL, Choi IH, Zhu G, Tamada K, Wang SD, Tamura H, Chapoval Al, Flies DB, Bajorath J, Chen L. B7-H4, a molecule of the B7 family, negatively regulates T cell immunity. Immunity. 2003;18(6):849-61.

51. Zhu Y, Yao S, Iliopoulou BP, Han X, Augustine MM, Xu H, Phennicie RT, Flies SJ, Broadwater M, Ruff W, et al. B7-H5 costimulates human T cells via CD28H. Nat Commun. 2013;4:2043.

52. Flies DB, Wang $\mathrm{S}, \mathrm{Xu} \mathrm{H}$, Chen L. Cutting edge: A monoclonal antibody specific for the programmed death-1 homolog prevents graft-versus-host disease in mouse models. J Immunol. 2011;187(4):1537-41.

53. Chen L. Co-inhibitory molecules of the B7-CD28 family in the control of Tcell immunity. Nat Rev Immunol. 2004;4(5):336-47.

54. Chen L, Flies DB. Molecular mechanisms of T cell co-stimulation and coinhibition. Nat Rev Immunol. 2013;13(4):227-42.

55. Schildberg FA, Klein SR, Freeman GJ, Sharpe AH. Coinhibitory Pathways in the B7-CD28 Ligand-Receptor Family. Immunity. 2016;44(5):955-72.

56. Dong H, Strome SE, Salomao DR, Tamura H, Hirano F, Flies DB, Roche PC, Lu J, Zhu G, Tamada K, et al. Tumor-associated B7-H1 promotes T-cell apoptosis: a potential mechanism of immune evasion. Nat Med. 2002;8(8): 793-800.

57. Freeman GJ, Long AJ, Iwai Y, Bourque K, Chernova T, Nishimura H, Fitz LJ, Malenkovich N, Okazaki T, Byrne MC, et al. Engagement of the PD-1 immunoinhibitory receptor by a novel B7 family member leads to negative regulation of lymphocyte activation. J Exp Med. 2000;192(7):1027-34.

58. Ishida Y, Agata Y, Shibahara K, Honjo T. Induced expression of PD-1, a novel member of the immunoglobulin gene superfamily, upon programmed cell death. EMBO J. 1992;11(11):3887-95.

59. Brunet JF, Denizot F, Luciani MF, Roux-Dosseto M, Suzan M, Mattei MG, Golstein P. A new member of the immunoglobulin superfamily-CTLA-4. Nature. 1987;328(6127):267-70.

60. Nishimura H, Nose M, Hiai H, Minato N, Honjo T. Development of lupus-like autoimmune diseases by disruption of the PD-1 gene encoding an ITIM motif-carrying immunoreceptor. Immunity. 1999;11(2):141-51.

61. Latchman $Y$, Wood CR, Chernova T, Chaudhary D, Borde M, Chernova I, Iwai Y, Long AJ, Brown JA, Nunes R, et al. PD-L2 is a second ligand for PD-1 and inhibits T cell activation. Nat Immunol. 2001;2(3):261-8.

62. Tseng SY, Otsuji M, Gorski K, Huang X, Slansky JE, Pai SI, Shalabi A, Shin T, Pardoll DM, Tsuchiya H. B7-DC, a new dendritic cell molecule with potent costimulatory properties for T cells. J Exp Med. 2001;193(7):839-46.

63. Iwai Y, Ishida M, Tanaka Y, Okazaki T, Honjo T, Minato N. Involvement of PDL1 on tumor cells in the escape from host immune system and tumor immunotherapy by PD-L1 blockade. Proc Natl Acad Sci U S A. 2002;99(19): 12293-7.

64. Curiel TJ, Wei S, Dong H, Alvarez X, Cheng P, Mottram P, Krzysiek R, Knutson $\mathrm{KL}$, Daniel B, Zimmermann MC, et al. Blockade of B7-H1 improves myeloid dendritic cell-mediated antitumor immunity. Nat Med. 2003;9(5):562-7.

65. Wang S, Bajorath J, Flies DB, Dong H, Honjo T, Chen L. Molecular modeling and functional mapping of B7-H1 and B7-DC uncouple costimulatory function from PD-1 interaction. J Exp Med. 2003;197(9):1083-91.

66. Butte MJ, Keir ME, Phamduy TB, Sharpe AH, Freeman GJ. Programmed death-1 ligand 1 interacts specifically with the B7-1 costimulatory molecule to inhibit T cell responses. Immunity. 2007;27(1):111-22.

67. Strome SE, Dong H, Tamura H, Voss SG, Flies DB, Tamada K, Salomao D, Cheville J, Hirano F, Lin W, et al. B7-H1 blockade augments adoptive T-cell immunotherapy for squamous cell carcinoma. Cancer Res. 2003;63(19):6501-5.

68. Dong H, Zhu G, Tamada K, Flies DB, van Deursen JM, Chen L. B7-H1 determines accumulation and deletion of intrahepatic CD8(+) T lymphocytes. Immunity. 2004;20(3):327-36. 
69. Latchman YE, Liang SC, Wu Y, Chernova T, Sobel RA, Klemm M, Kuchroo VK, Freeman GJ, Sharpe AH. PD-L1-deficient mice show that PD-L1 on T cells, antigen-presenting cells, and host tissues negatively regulates T cells. Proc Natl Acad Sci U S A. 2004;101(29):10691-6.

70. Hirano F, Kaneko K, Tamura H, Dong H, Wang S, Ichikawa M, Rietz C, Flies DB, Lau JS, Zhu G, et al. Blockade of B7-H1 and PD-1 by monoclonal antibodies potentiates cancer therapeutic immunity. Cancer Res. 2005;65(3):1089-96.

71. Iwai Y, Terawaki S, Honjo T. PD-1 blockade inhibits hematogenous spread of poorly immunogenic tumor cells by enhanced recruitment of effector $T$ cells. Int Immunol. 2005;17(2):133-44.

72. Barber DL, Wherry EJ, Masopust D, Zhu B, Allison JP, Sharpe AH, Freeman GJ, Ahmed R. Restoring function in exhausted CD8 T cells during chronic viral infection. Nature. 2006;439(7077):682-7.

73. Brahmer JR, Drake CG, Wollner I, Powderly JD, Picus J, Sharfman WH, Stankevich E, Pons A, Salay TM, McMiller TL, et al. Phase I study of singleagent anti-programmed death-1 (MDX-1106) in refractory solid tumors: safety, clinical activity, pharmacodynamics, and immunologic correlates. J Clin Oncol. 2010;28(19):3167-75.

74. Topalian SL, Hodi FS, Brahmer JR, Gettinger SN, Smith DC, McDermott DF Powderly JD, Carvajal RD, Sosman JA, Atkins MB, et al. Safety, activity, and immune correlates of anti-PD-1 antibody in cancer. N Engl J Med. 2012; 366(26):2443-54

75. Brahmer JR, Tykodi SS, Chow LQ, Hwu WJ, Topalian SL, Hwu P, Drake CG, Camacho LH, Kauh J, Odunsi K, et al. Safety and activity of anti-PD-L1 antibody in patients with advanced cancer. N Engl J Med. 2012;366(26): 2455-65.

76. Taube JM, Anders RA, Young GD, Xu H, Sharma R, McMiller TL, Chen S, Klein AP, Pardoll DM, Topalian SL, et al. Colocalization of inflammatory response with B7-h1 expression in human melanocytic lesions supports an adaptive resistance mechanism of immune escape. Sci Transl Med. 2012;4(127):127ra137.

77. Poole RM. Pembrolizumab: first global approval. Drugs. 2014;74(16):1973-81.

78. Sul J, Blumenthal GM, Jiang X, He K, Keegan P, Pazdur R. FDA Approval Summary: Pembrolizumab for the Treatment of Patients With Metastatic Non-Small Cell Lung Cancer Whose Tumors Express Programmed DeathLigand 1. Oncologist. 2016;21(5):643-50.

79. Kazandjian D, Suzman DL, Blumenthal G, Mushti S, He K, Libeg M, Keegan P, Pazdur R. FDA Approval Summary: Nivolumab for the Treatment of Metastatic Non-Small Cell Lung Cancer With Progression On or After Platinum-Based Chemotherapy. Oncologist. 2016;21(5):634-42.

80. Raedler LA. Opdivo (Nivolumab): Second PD-1 Inhibitor Receives FDA Approval for Unresectable or Metastatic Melanoma. Am Health Drug Benefits. 2015;8(Spec Feature):180-3.

81. Goodman A, Patel SP, Kurzrock R. PD-1-PD-L1 immune-checkpoint blockade in B-cell lymphomas. Nat Rev Clin Oncol. 2016. doi:10.1038/nrclinonc.2016.168.

82. Nods for Atezolizumab and Nivolumab from FDA. Cancer Discov. 2016;6(8):811.

83. Markham A. Atezolizumab: First Global Approval. Drugs. 2016;76(12):1227-32.

84. Sznol M, Chen L. Antagonist antibodies to PD-1 and B7-H1 (PD-L1) in the treatment of advanced human cancer. Clin Cancer Res. 2013;19(5):1021-34.

85. Tontonoz M, Gee CE. Cancer immunotherapy out of the gate: the 22 nd annual Cancer Research Institute International Immunotherapy Symposium. Cancer Immunol Res. 2015;3(5):444-8.

86. Selenko-Gebauer N, Majdic O, Szekeres A, Hofler G, Guthann E, Korthauer U, Zlabinger G, Steinberger P, Pickl WF, Stockinger $\mathrm{H}$, et al. B7-H1 (programmed death-1 ligand) on dendritic cells is involved in the induction and maintenance of T cell anergy. J Immunol. 2003;170(7):3637-44.

87. Tsushima F, Yao S, Shin T, Flies A, Flies S, Xu H, Tamada K, Pardoll DM, Chen $\mathrm{L}$. Interaction between $\mathrm{B} 7-\mathrm{H} 1$ and PD-1 determines initiation and reversal of T-cell anergy. Blood. 2007;110(1):180-5.

88. Goldberg MV, Maris CH, Hipkiss EL, Flies AS, Zhen L, Tuder RM, Grosso JF, Harris TJ, Getnet D, Whartenby KA, et al. Role of PD-1 and its ligand, B7-H1, in early fate decisions of CD8 T cells. Blood. 2007;110(1):186-92.

89. Francisco LM, Salinas VH, Brown KE, Vanguri VK, Freeman GJ, Kuchroo VK, Sharpe AH. PD-L1 regulates the development, maintenance, and function of induced regulatory T cells. J Exp Med. 2009;206(13):3015-29.

90. Amarnath S, Mangus CW, Wang JC, Wei F, He A, Kapoor V, Foley JE, Massey PR, Felizardo TC, Riley JL, et al. The PDL1-PD1 axis converts human TH1 cells into regulatory T cells. Sci Transl Med. 2011;3(111):111ra120.

91. Yao S, Wang S, Zhu Y, Luo L, Zhu G, Flies S, Xu H, Ruff W, Broadwater M, Choi $\mathrm{IH}$, et al. PD-1 on dendritic cells impedes innate immunity against bacterial infection. Blood. 2009:113(23):5811-8.
92. Azuma T, Yao S, Zhu G, Flies AS, Flies SJ, Chen L. B7-H1 is a ubiquitous antiapoptotic receptor on cancer cells. Blood. 2008;111(7):3635-43.

93. Petroff MG, Chen L, Phillips TA, Hunt JS. B7 family molecules: novel immunomodulators at the maternal-fetal interface. Placenta. 2002;23(Suppl A): S95-101.

94. Naidoo J, Page DB, Li BT, Connell LC, Schindler K, Lacouture ME, Postow MA, Wolchok JD. Toxicities of the anti-PD-1 and anti-PD-L1 immune checkpoint antibodies. Ann Oncol. 2015;26(12):2375-91.

95. Sharma P, Allison JP. The future of immune checkpoint therapy. Science. 2015;348(6230):56-61.

\section{Submit your next manuscript to BioMed Central and we will help you at every step:}

- We accept pre-submission inquiries

- Our selector tool helps you to find the most relevant journal

- We provide round the clock customer support

- Convenient online submission

- Thorough peer review

- Inclusion in PubMed and all major indexing services

- Maximum visibility for your research

Submit your manuscript at www.biomedcentral.com/submit
Biomed Central 